\title{
Visitor's willingness to pay for cultural ecosystem services in Bangladesh: an assessment for Lawachara National Park, a biodiversity hotspot
}

\section{Narayan Saha}

Shahjalal University of Science and Technology School of Agriculture and Mineral Sciences

Sharif A. Mukul ( $D$ smukul@usc.edu.au )

University of the Sunshine Coast https://orcid.org/0000-0001-6955-2469

\section{Research Article}

Keywords: cultural ecosystem service, ecotourism, Lawachara National Park, travel cost method, willingness to pay

Posted Date: March 8th, 2021

DOl: https://doi.org/10.21203/rs.3.rs-269549/v1

License: (c) (i) This work is licensed under a Creative Commons Attribution 4.0 International License. Read Full License

Version of Record: A version of this preprint was published at Small-scale Forestry on November 12th, 2021. See the published version at https://doi.org/10.1007/s11842-021-09494-5. 


\section{Abstract}

The valuation of natural ecosystems helps policymakers in allocate adequate resources for the provision of ecosystem services they provide. Cultural ecosystem services are the non-material benefits we obtain from nature, which include but are not limited to recreation, aesthetic enjoyment, physical and mental health benefits. They are essential for a proper sense of a place, human health, and wellbeing. We quantified the recreational and other non-material benefits of Lawachara National Park (LNP), one of the oldest and most diverse forest protected area and touristic attractions in northeast Bangladesh. A Modified Travel Cost Method (MTCM) was applied for quantifying the recreational and other non-material values of LNP. Altogether 309 respondents were interviewed, covering both peak season and slack season. In our MTCM, we considered several additional factors, unlike the commonly used Travel Cost Method (TCM). The value of cultural ecosystem services of LNP was estimated to be Taka 1476.70 million and Taka 476.44 million per annum using MTCM and TCM, respectively. The value estimated using MTCM was marginally higher than the value estimated using TCM and was due to the additional variables we considered in our modified approach. We believe our estimates using MTCM will guide policymakers to properly value natural ecosystems and facilitate adequate resource allocation for ecotourism in LNP and elsewhere.

\section{Introduction}

Forests are vital for providing us with a wide range of regulating, provisioning, and cultural ecosystem services (Ota et al. 2021; Saha 2021; Landell-Mills and Porras 2002). Regulating and provisioning ecosystem services mainly represents material benefits from the forest, such as biodiversity conservation, carbon sequestration, climate regulation, water retention, nutrient cycling (Sinha and Baten 2021; Mukul et al. 2017a). Cultural ecosystem services, on the other hand, represent non-material benefits, like recreation, aesthetic enjoyment, physical and mental health benefits that we derive from forests (Nadiruzzaman and Rahman 2021), and are still underrepresented in literature due to the complexity of their nature (Ezebilo 2016).

In forest areas, cultural ecosystem service also generates revenue through recreational benefits, which usually is an experience of enjoyment resulting from a complex interaction between travellers, their trip objective, usual environment and cultural background, the forest biodiversity, and other things (Sands 2005; Pant 1984). Recreational opportunity in forest areas also generates employment and income needed for the local development (Pant 1984). Over the past decades, the ecotourism industry has been expanding worldwide due to its relatively lesser ecological footprint (Lenzen et al. 2018), and potentials to contributes to the maintenance of species and habitats either directly through conservation or indirectly by providing the local community with sufficient revenue (Drumm and Moore 2005; Goodwin et al. 1999). Ecotourism also encourages local people to value and protect wildlife heritage as a source of income (Mree et al. 2020; Mukul et al. 2012; Weaver 2008). 
In Bangladesh, nature-based tourism increasingly becoming popular in the last few years with the advancement of country's economic development, increased road networks, and access to social media (e.g. Facebook) (Salam et al. 2000). A large and growing urban population and expansion of protected areas in the country, in recent years also fuelled increasing visits to forest areas for recreation, aesthetic enjoyment, other mental health benefits (Mukul et al. 2017b). Some of these forest protected areas provide free entrance or a nominal entrance fee and thus fail to appear the real value in national accounts and these values ascribed to other parts of the economy. Consequently, the revenue earned from cultural ecosystem services cannot be used for the management of natural ecosystems in the country (Mukul et al. 2018).

Travel cost method (TCM) has widely been used for the estimation of recreational sites globally (see Solikin et al. 2019; Ortega et al. 2018; Muryani and Prabugati 2016; Islam and Majumder 2015; Spacek and Antouskova 2013; Bharali and Mazumder 2012; Bateman et al. 1996). TCM estimates the value of non-market goods and services, such as recreational sites, and assumes that this value reflects by how many people are willing to pay to get there (Limaei et al. 2014). The basic premise of the TCM is the costs of time and travel expenses incurred by the individual travellers while visiting a recreational site (Leh et al. 2018). Therefore, the willingness to pay of visitors to visit a recreation site can be determined based on the number of trips at different travel costs. This method is called a revealed preference method because environmental values are estimated based on the actual behaviour and choices of the peoples rather than verbal responses to hypothetical scenarios (Limaei et al. 2014). TCM is relatively uncontroversial because it is modified on standard economic techniques for measuring value.

Although TCM is considered as a robust method for the valuation of recreational sites (Solikin et al. 2019; Limaei et al. 2017; Spacek and Antouskova 2013), the method has several limitations. For instance, multipurpose and multi-destination trips are not considered in the TCM leading to an overestimation of the recreational value of a particular site (Leh et al. 2018; CBA 2014). Likewise, other costs involved in entry to recreational site, charges associated with dormitory, guest house, picnic spot, parking, guide, toilet, film shooting, etc. are not considered resulting in underestimating a site (Loomis et al. 2000). These technical aspects need to be considered while estimating recreational site values (World Bank 1995).

Here, we applied a Modified Travel Cost Method (MTCM) for quantifying the recreational and other nonmaterial benefits of Lawachara National Park (LNP) - one of the oldest forest protected areas of the country with rich biological and cultural heritage. We considered several additional factors in our MTCM, unlike the commonly used Travel Cost Method (TCM), which we believe minimize the uncertainty resulting from possible overestimation or underestimation of a particular site. The novelty of this study is to consider the variables, such as the costs of multi-purpose and multi-destination visits, while estimating the value of a recreational site. There have been very few studies in Bangladesh on cultural ecosystem services and/or recreation and other non-material benefits from forests (see - Kawsar et al. 2015; Uddin et al. 2013). Our study, therefore, will also help policymakers and forest managers in resource allocation problems in LNP and other sites of biological and cultural significance in the country. 


\section{Materials And Methods}

\subsection{The study area}

LNP has an area of about 1,250 ha, and geographically it is located between $24^{0} 30^{\prime}-24^{0} 32^{\prime} \mathrm{N}$ latitude and $91^{0} 37^{\prime}-91^{0} 39^{\prime}$ E longitude (Mukul and Saha 2017). The park is located approximately $185 \mathrm{~km}$ northeast of Dhaka, the capital city of Bangladesh (Islam et al. 2019; Figure 1). LNP was declared as a national park on July 07, 1996, by the gazette notification no 367 (Mukul et al. 2017). The park is an IUCN category II protected area and is located under civil administrative unit of Kamalganj Upazilla, Moulvibazar district of Sylhet division (Mukul 2008).

The forest in LNP is semi-evergreen in nature, and it is located in the wettest region of the country (Mukul 2014). The park area is a habitat of at least 167 species of plants, 4 species of amphibians, 6 species of reptiles, 246 species of birds, 20 species of mammals, and 17 insect species (Pavel et al. 2016; Quazi and Ticktin 2016; Uddin and Hassan 2010). This park also represents one of the largest habitats of the critically endangered western Hoolock gibbon in the country (Hasan et al. 2020). The Khasia indigenous community lives within the forest and cultivates betel leaves using forest trees as support for betel vines (Mukul and Saha 2017; Saha and Azam 2004).

LNP is famous for ecotourism, where tourists come all over the year, with the majority comes during the winter. LNP is extensively used by the visitors for seeing trees and landscapes, wildlife-watching and enjoying fresh-weather of nature (Rahman and Shil 2012). LNP is surrounded by several tea gardens, which have also become attraction for tourists (Sohel et al. 2015). Two important tourist attractions, namely Madhabpur Lake and Satchari National Park (SNP), are situated nearby LNP. Furthermore, a local zoo and wildlife rescue center managed by Mr. Sitesh Ranjan Deb, and a large waterbody called Baikka Beel, which is famous for migratory birds and water lilies, is also located near LNP (Figure 2).

\subsection{Field surveys and data collection}

There are 2 recreational seasons in LNP, i.e. peak season (October to March) and slack season (April to September). Friday and Saturday are the weekends in Bangladesh. Data for this study were collected through interview surveys supplemented by a semi-structure questionnaire during January 2019 and April 2019. A reconnaissance survey was carried out prior to the intensive interview surveys. During reconnaissance survey, we trained up several research assistants and/or field investigators for conducting the field survey. Our reconnaissance survey was supplemented by a semi-structure questionnaire. A final semi-structure questionnaire was developed based on our recon2.naissance surveys.

We conducted a total 18-day surveys, 9 days in peak and 9 days in slack season. Our survey period includes 4 weekends and 5 weekdays. Individuals and groups who visited the park were selected randomly as our respondents. In case of group visitors, only group head was selected as respondent to 
avoid any repetition of the transportation costs. Altogether we interviewed 309 visitors, which corresponds all major visitors' type in LNP.

Visitors were surveyed at the time of their return from the park. We collected demographic and socioeconomic characteristics of the visitors, such as age, average monthly income, education levels and site visit type (i.e. group or individual). Three categories of visitors (student, adult, and foreigner) required to purchase ticket for entering the LNP. During our survey period, every afternoon after closing the entrance of the visitors to the park, we also asked the ticket sellers of the park about the category wise total number of visitors (based on the sale of ticket) on that day. Thus, our sample size represents a sampling intensity of $3.10 \%$.

Other travel characteristics, such as the origin of the travel (the starting point of the journey), purposes of visit, main destination, other costs (activity expenses as fees for entrance, dormitory, guest house, picnic spot, parking, guide, toilet, film shooting and so on) was also noted for each respondent. Other costs did not consider the food values, because food is an essential commodity, tourists must take it wherever they are staying.

The origin of travel was categorised into five zones based on their distances from LNP. Each zone has a radius of $100 \mathrm{~km}$. Other travel related parameters such as transportation cost (round transport costs of the visitor in Tk), travel time (round travel time plus time spent in the park) in hour, travel distance (round travel distance in $\mathrm{km}$ ) was also gathered. Means of travel was categorized as reserved vehicles (micro bus; bus; car; crude natural gas operated three wheelers) and public vehicles (bus, train, crude natural gas operated three wheelers).

Individuals travelling to a recreation site only due to other reasons, such as research, study tour, official visit considered as pure tourists, because they spent money to access in the park. In case of meanderer tourists, like multi-purpose and multi-destination tourists, they were asked about the main destination. If main destination was LNP, then the extra amount of money spent for transportation was asked, for example, if a tourist rents a micro-bus, he/she had to pay additional amount of money to visit other places, which was subtracted from total amount of transportation fare. Likewise, if main destination was other sites, such as Madhabpur Lake or SNP (Figure 1) and so on, only the additional amount for visiting LNP was count as transportation cost.

Opportunity cost of time would be in meanderer cases, time costs needed to reach LNP from the origin of starting the journey and the time spent in the park. If in both cases, origin of starting the journey would be for examples, a tourist visiting in Moulvibazar from Dhaka for business purpose for last 3 days, visiting LNP at the time of survey, so in that case, origin of starting the journey would be Moulvibazar. Another example, if a tourist visiting some recreation sites from Dhaka, tourist's origin of starting the journey to LNP would be Dhaka, if tourist visited other places before entering LNP, the extra time deducted from total time or if tourist would visit other places after LNP, then time counted as usual.

\subsection{Valuation of recreational and other non-material benefits}


Among the three types of TCM that are used in estimating values of recreational sites (i.e. Zonal Travel Cost Method or ZTCM; Individual Travel Cost Method or iTCM, and Random Utility Travel Cost Method or ruTCM), we used zTCM which is straightforward, and less expensive. The following equation was used to determine the travel cost or the recreational and other non-material value of LNP (V) (CBA 2014):

$V=\{(T \times w)+(D \times v)+C a\} \times V a$

Where, $\mathrm{T}=$ travel time in hour; $\mathrm{w}=$ average wage rate in Taka/hour; $\mathrm{D}=$ distance in $\mathrm{km} ; \mathrm{v}=$ marginal vehicle operating cost in Taka/ $\mathrm{km} ; \mathrm{Ca}=$ cost of admission to site (entry fee); $\mathrm{Va}=$ estimated number of visits per year for each zone.

While, TCM uses transportation costs, visitors' opportunity costs of the time spent travelling to that site and entry fees for valuation of recreational sites. The MTCM strengthens the valuation of recreational sites through the existing TCM combined with multi-purpose and multi-destination trips, on-site expenditures including entry fees as additional variables. MTCM, therefore, minimize the limitations of the existing TCM.

Multi-purpose trip refers to individuals travelling to a recreation site due to other reasons rather than recreation (Menkhaus and Lober 1996). In most of the cases, individuals travelling to a recreational site due to recreation, but they stay in other places for purposes, like businesses and so on. Multi-destination trip refers to individuals travelling more than one specific recreational site in a single go (Leh et al. 2018). The value of a recreational site $(\mathrm{V})$ for each zone can be estimated by using the following equation of MTCM:

$V=\left[(T \times w)+\{(D \times v)-M\}+\sum O C\right] \times V a$

Where, $\mathrm{T}=$ travel time in hour; $\mathrm{w}=$ average wage rate in Taka/hour; $\mathrm{D}=$ distance in $\mathrm{km} ; \mathrm{v}=$ vehicle operating cost in Taka/km; $\mathrm{M}=$ multi-purpose/multi-destination visit cost; $\sum \mathrm{OC}=$ summation of on-site expenditures (entry fees, dormitory/guest house, picnic spot, parking, guide, toilet, film shooting and so on); $\mathrm{Va}=$ estimated number of visits per year for each zone. Summation of $\mathrm{V}$ values of all zones will give travel cost or the proxy price to access in a recreational site or value of a recreational site.

The demand function usually estimated based on the relation between travel cost per zone and visits rate (number of visitors from a zone to a recreation site divided by the total number of populations of that zone). Willingness to pay (WTP) of a visitor to visit a recreational site can be estimated as follows:

$\mathrm{WTP}=\mathrm{V} / \mathrm{N}$

Where, $\mathrm{V}=$ value of the recreational site and $\mathrm{N}=$ total number of visits per annum.

The steps involved in our MTCM are illustrated in Figure 3.

We carried out regression analysis to determine the correlation between travel cost per zone and visit rates per zone. Factor 1.79 was used to estimate the actual number of visitors per day. This factor was 
estimated by using the following formula as described in Kawsar, et al. (2015):

$\{(\mathrm{Tv} / \mathrm{Nd}) / \mathrm{Ov}\}$

Where, $\mathrm{TV}=$ actual number of visitors in survey period, $\mathrm{Nd}=$ number of days surveyed, and $\mathrm{Ov}=$ observed number of visitors in survey period.

\section{Results}

\section{1 Characteristics of the respondents}

Table 1 shows the socio-economic and demographic features of the respondents. The maximum number of tourists visited LNP belonged to age category 21-40 years, educated, and both high income and no income groups. Most of the students, housewives and foreigners belonged to no income group. About $98 \%$ of the tourists came to the LNP as group. More than a half of the visitors (63\%) visited LNP in peak season. There was no big difference in the vehicle use by the visitors as $47 \%$ of the visitors used reserved vehicles and $53 \%$ of the visitors used public vehicles. The most used reserved vehicle was micro bus (43\%), followed by bus (41\%), car (14\%), while the least used reserved vehicle was crude natural gas (CNG) operated three wheelers ( $2 \%$ ). The main destination of $48 \%$ of the visitors was LNP, and recreation was the sole purpose of majority $(98 \%)$ of the visitors.

Table 1. Characteristics of the respondents $(N=309)$. 


\begin{tabular}{|c|c|c|c|}
\hline Characteristics & Category & Frequency & Relative frequency (\%) \\
\hline \multirow[t]{4}{*}{ Age groups (years) } & $<21$ & 35 & 11.33 \\
\hline & $21-40$ & 197 & 63.75 \\
\hline & $41-60$ & 76 & 24.60 \\
\hline & $>60$ & 1 & 0.32 \\
\hline \multirow[t]{3}{*}{ Education } & Primary & 0 & 0 \\
\hline & Secondary & 40 & 12.94 \\
\hline & Higher Secondary and above & 269 & 87.06 \\
\hline \multirow[t]{6}{*}{ Income groups (Taka/month) } & No income & 92 & 29.77 \\
\hline & Up to 10,000 & 29 & 9.39 \\
\hline & $10,001-20,000$ & 11 & 3.56 \\
\hline & $20,001-30,000$ & 25 & 8.09 \\
\hline & $30,001-40,000$ & 43 & 13.92 \\
\hline & $>40,000$ & 109 & 35.28 \\
\hline \multirow[t]{4}{*}{ Purposes of visit } & Recreation & 304 & 98.38 \\
\hline & Study tour & 3 & 0.97 \\
\hline & Research & 1 & 0.32 \\
\hline & Official & 1 & 0.32 \\
\hline \multirow[t]{2}{*}{ Seasonal tourists } & Peak & 196 & 63.43 \\
\hline & Slack & 113 & 36.57 \\
\hline \multirow[t]{2}{*}{ Category of tourists } & Group & 303 & 98.06 \\
\hline & Individual & 6 & 1.94 \\
\hline \multirow[t]{2}{*}{ Types of tourist } & Pure & 147 & 47.57 \\
\hline & Meanderer & 162 & 52.43 \\
\hline \multirow[t]{2}{*}{ Vehicles } & Reserved & 145 & 46.93 \\
\hline & Public & 164 & 53.07 \\
\hline
\end{tabular}

\subsection{Relationship between travel cost and visiting LNP}

The highest number $(n=183)$ of tourist visited per day in the LNP was from Dhaka, which is about 185 $\mathrm{km}$ away from the LNP (Table 2). Dhaka belongs to B zone (101-200 km) and require an average Taka 3,070.36 using MTCM and Taka 3,125.96 using TCM as travel costs to access LNP (Table 2). Next to Dhaka was Sylhet (107 tourists/day) which belongs to A zone $(0-100 \mathrm{~km})$. Sylhet is about $91 \mathrm{~km}$ away from the LNP and costs an average Taka 1,621.54 using MTCM and Taka 1,589.06 using TCM to access LNP (Table 2).

The highest rate of visits per total population was 2.64 accounted for A zone, where the travel costs were lowest Taka 1,270.80 using MTCM and Taka 1,252.13 using TCM (Table 2). The visits per total population were $0.81,0.22,0.10$ and 0.07 accounted for B, C, D and E zones respectively (Table 2). The travel costs of B, C, D and E zones were respectively Taka 2,889.93, Taka 3,615.32, Taka 4,893.43 and Taka 5,597.47 using the MTCM, and respectively Taka 2,897.45, Taka 3,653.69, Taka 4,944.26 and Taka $5,410.70$ using the TCM (Table 2; Supplementary material 1). 
Our regression analysis revealed the demand functions of MTCM and TCM (Figure 4 and 5). In both cases, the number of visits per total population decreased with increasing travel costs. The inverse relationship was strong both in case of $\operatorname{MTCM}\left(R^{2}=0.97, p<0.01\right)$ and $\operatorname{TCM}\left(R^{2}=0.98, p<0.01\right)$.

Table 2. Relationship between travel cost and visiting LNP.

\begin{tabular}{|c|c|c|c|c|c|c|c|}
\hline $\begin{array}{l}\text { Zone and } \\
\text { Districts }\end{array}$ & $\begin{array}{c}\text { Distance } \\
\text { from } \\
\text { LNP } \\
(\mathrm{km}) \\
\end{array}$ & Population & $\begin{array}{l}\text { Observed } \\
\text { number of } \\
\text { visitors in } \\
18 \text { days }\end{array}$ & $\begin{array}{l}\text { Actual number of } \\
\text { visitors in a single } \\
\text { day }\end{array}$ & $\begin{array}{c}\text { Visits per } \\
100,000 \\
\text { population /day }\end{array}$ & $\begin{array}{c}\text { Travel cost } \\
\text { using } \\
\text { MTCM } \\
\text { (Taka/trip) }\end{array}$ & $\begin{array}{l}\text { Travel cost } \\
\text { using TCM } \\
\text { (Taka/trip) }\end{array}$ \\
\hline $\mathrm{A}(0-100 \mathrm{~km})$ & 48.00 & $8,491,000$ & 124 & 222 & 2.64 & $1,270.80$ & $1,252.13$ \\
\hline Moulvibazar & 30 & $2,148,000$ & 39 & 70 & 3.33 & 842.71 & 829.01 \\
\hline Habiganj & 53 & $2,386,000$ & 25 & 45 & 1.96 & $1,269.20$ & $1,259.36$ \\
\hline Sylhet & 61 & $3,957,000$ & 60 & 107 & 2.74 & $1,621.54$ & $1,589.06$ \\
\hline $\begin{array}{l}\text { B (101-200 } \\
\mathrm{km})\end{array}$ & 157.29 & $34,327,000$ & 155 & 277 & 0.81 & $2,889.93$ & $2,897.45$ \\
\hline Brahmanbaria & 104 & $3,255,000$ & 13 & 23 & 0.72 & $1,952.53$ & $1,816.73$ \\
\hline Narsingdi & 146 & $2,489,000$ & 14 & 25 & 1.04 & $2,762.65$ & $2,785.58$ \\
\hline Sunamganj & 146 & $2,800,000$ & 4 & 7 & 0.25 & $2,950.53$ & $2,906.84$ \\
\hline Kishoregan & 161 & $3,311,000$ & 6 & 11 & 0.33 & $3,021.84$ & $3,123.44$ \\
\hline Cumilla & 167 & $6,046,000$ & 9 & 16 & 0.27 & $2,773.57$ & $2,777.21$ \\
\hline Dhaka & 185 & $13,142,000$ & 102 & 183 & 1.40 & $3,070.36$ & $3,125.96$ \\
\hline Narayanganj & 192 & $3,284,000$ & 7 & 13 & 0.41 & $3,362.40$ & $3,410.81$ \\
\hline $\begin{array}{l}\mathrm{C}(201-300 \\
\mathrm{km})\end{array}$ & 265.50 & $17,030,000$ & 21 & 38 & 0.22 & $3,615.32$ & $3,653.69$ \\
\hline Gazipur & 201 & $3,809,000$ & 11 & 20 & 0.53 & $3,955.33$ & $3,811.49$ \\
\hline Mymensingh & 228 & $5,807,000$ & 5 & 9 & 0.16 & $3,196.53$ & $3,320.12$ \\
\hline Noakhali & 241 & $3,491,000$ & 2 & 4 & 0.12 & $3,649.56$ & $3,879.14$ \\
\hline Tangail & 246 & $3,923,000$ & 3 & 5 & 0.13 & $4,030.67$ & $3,974.84$ \\
\hline $\begin{array}{l}\mathrm{D}(301-400 \\
\mathrm{km})\end{array}$ & 350.00 & $12,746,000$ & 7 & 13 & 0.10 & $4,893.43$ & $4,944.26$ \\
\hline Chattogram & 317 & $8,440,000$ & 3 & 5 & 0.06 & $4,512.71$ & $4,520.21$ \\
\hline Jessore & 350 & $3,029,000$ & 2 & 4 & 0.13 & 5,497 & 5,612 \\
\hline Gopalganj & 383 & $1,277,000$ & 2 & 4 & 0.33 & $5,340.32$ & $5,370.32$ \\
\hline $\begin{array}{l}\mathrm{E}(401-500 \\
\mathrm{km})\end{array}$ & 405.00 & $5,697,000$ & 2 & 4 & 0.07 & $5,597.47$ & $5,410.70$ \\
\hline Naogaon & 405 & $2,844,000$ & 1 & 2 & 0.07 & $6,509.20$ & $5,904.20$ \\
\hline Rajshahi & 405 & $2,853,000$ & 1 & 2 & 0.07 & $4,685.74$ & $4,917.20$ \\
\hline \multicolumn{6}{|c|}{ Annual travel cost/value of LNP (in Million taka) } & 476.70 & 476.44 \\
\hline
\end{tabular}

\subsection{Value of LNP and WTP}

The value of the LNP was estimated to be Taka 476.70 million per annum using MTCM, while it was estimated to be Taka 476.44 million per annum using TCM. The estimated WTP of each visitor to visit the LNP was Taka 2,357.43 using MTCM and Taka 2,356.18 using TCM. About 40\% of the visitors of the LNP originated their travel from A zone. They were benefited Taka 1,086.63/trip using MTCM and Taka $1,104.05 /$ trip using TCM, by visiting the LNP. Our estimation also suggests that about $60 \%$ visitors of LNP paid excess amount of money. 
The entry fees to the LNP for student, adults and foreigners were Taka 20, Taka 50 and Taka 500, respectively. During the survey, we also asked the tourists whether they were willing to pay some extra amount of money as entry fee for the improvement of the park and for biodiversity conservation. More than $60 \%$ of the total visitors responded positively and were willing to pay Taka 50 for student and Taka 100 adult entrance fee to the park. This would generate an additional Taka 8.38 million per annum.

\section{Discussion}

Both MTCM and TCM are quantitative assessment method and shows the actual behavior of the tourists as both methods are based on revealed preferences (Das 2013). The revealed preference approach assumes that observed behavior follows from an intrinsic utility maximization process (Limaei et al. 2017). TCM is widely used for valuing recreational services around the world and is also believed to better than the Contingent Valuation Method and Hedonic Price Method, which use willingness to pay in a hypothetical situation rather than the actual behavior of the visitor (Ward 2000; Pant 1984). In TCM, however, there is no consensus about calculating the values for multi-purpose and multi-destination visits (Loomis 2000). The MTCM, that we used in the present study is TCM with some refinements, eliminates the chances of underestimating and overestimating the value, thus offering a more appropriate value of natural recreational sites.

In our study, the value estimated by using the MTCM is marginally higher than the TCM. It does not mean, the application of the MTCM has not been shown any significant differences from using the TCM. The essence of the application of the MTCM is that it controls the chances of overestimation and underestimation of the value of a particular recreation site. When the values of multi-purpose and multidestination visits were lower than the values of other costs excluding entry fee, the travel costs to excess the LNP were higher in the MTCM than the TCM and vice-versa. The entry fee is the common variable for the TCM and the MTCM, resulting in no difference in the values estimated by the TCM and the MTCM. Our study also reveals that it is essential to consider the values of multi-purpose and multi-destination visits and other costs or on-spot expenditures while estimating recreational sites' values by using the MTCM for more accurate results.

In our study, there was an inverse relationship between the number of visitors and the travel cost. That is, if travel costs increase, the number of visits (and visitors) will decrease, and vice-versa. However, visitors from B zone were maximum, although the travel cost of this zone was not cheaper than the A zone. There might have several reasons behind this. B zone included Dhaka, the capital city of Bangladesh, characterized by a high population density, with a population of a high-income group and a high literacy rate. A higher number of visitors from Dhaka arguably can also be due to good transportation systems between Dhaka and the LNP (Elands et al. 2015; Kawsar et al. 2015).

There were no visitors from most of the districts of Bangladesh due to long distances and associated high travel costs. Our study also finds a higher visitation rate per population with the lowest travel cost. The origin of the journey does not mean the home district of the traveller. If the study considers the home 
district of the travellers, then it is possible to catch the travellers from all the districts of Bangladesh. There is also a minimal chance of visiting LNP from the districts where there are already forest protected areas and other environmental recreational sites (Kawsar et al. 2015).

The value of forest protected areas like LNP is incredibly significant for the national development of Bangladesh. Local inhabitants of such protected areas need socio-economic protection, and ecotourism development can ensure the protection and conservation of biodiversity (Mree et al. 2020; Rana et al. 2010). With increasing population, urbanization, and economic development, the demand for recreation in protected areas will steadily increase (Lenzen et al. 2018). The WTP indicates that the LNP management authority has ample scope to increase the entry fee for generating an extra amount of money for the development of the park and biodiversity conservation.

\section{Conclusion}

Although the TCM is an old method for estimating the values of cultural ecosystem services, and more particularly, recreational sites, the MTCM approach used in our study is the first attempt in Bangladesh and provided more accurate and robust results by eliminating the chances of overestimation or underestimation. Our modified approach considers the variables, such as the costs of multi-purpose and multi-destination visits, while estimating the value of main cultural ecosystem services of LNP. Our study will help policymakers and forest managers in proper resource allocation to manage and protect biologically and culturally significant areas of national importance both in Bangladesh and elsewhere.

\section{Declarations}

\section{Funding}

The study was supported by a grant (Project no. FES/2018/3/08) from the Shahjalal University of Science and Technology, Sylhet, Bangladesh.

\section{Conflict of interest}

The authors declare that they have no known competing financial interests or personal relationships that could have appeared to influence the work reported in this paper.

\section{Availability of data and material}

Supplementary data related to this manuscript/study has been provided as Supplementary material 1 .

\section{Authors' contribution}

Conceptualization: Narayan Saha (NS) and Sharif A. Mukul (SAM); Methodology: NS and SAMl; Investigation: NS and SAM; Data curation and Formal analysis: NS; Writing - Original Draft: NS and SAM; Project administration: NS. 


\section{Acknowledgements}

The authors are grateful to Dr. Mizaur Rahman for his comments and suggestions on an earlier version of this manuscript. Thanks also due to Subhashis Das and Md. Rahimullah Miah for assistance in field data collection. We gratefully acknowledge the cooperation and support from the respondents and park officials during the study.

\section{References}

Bateman, I. J., Garrod, G.D., Brainard, J. S., Lovett, A. A. 1996. Measurement issues in the travel cost method: a geographic information systems approach. Journal of Agricultural Economics, 47: 191-205.

Bharali, A., Mazumder, R. 2012. Application of travel cost method to assess the pricing policy of public parks: the case of Kaziranga National Park. Journal of Regional Development and Planning. 1: 44-52.

Carey, O.L. 1965. The economics of recreation: progress and problems. Economic Enquiry, 3: 172-182.

CBA. 2014. Travel cost method (TCM). http://www.cbabuilder.co.uk/Quant4.html

Das, S. 2013. Travel Cost Method for Environmental Valuation. Dissemination Paper 23, Center of Excellence in Environmental Economics, Madras School of Economics, Chennai, India.

Drumm, A., Moore, A. 2005. Ecotourism development: a manual for conservation planners and managers. Second Edition. Vol. I, The Nature Conservancy. Arlington, Virginia, USA.

Elands, B., Islam, M.W., Duim, R.V.D. 2015. Ecotourism in Lawachara National Park in Bangladesh: Perceptions of Local People and Co-Management Officials. South Asian Journal of Tourism and Heritage, 8: 1-20.

Ezebilo, E.E. 2016. Economic value of a non-market ecosystem service: an application of the travel cost method to nature recreation in Sweden. International Journal of Biodiversity Science, Ecosystem Services \& Management, 12: 314-327.

Goodwin, H., Kent, I., Parker, K., Walpole, M. 1999. Tourism, Conservation and Sustainable Development: Case studies from Asia and Africa. International Institute of Environment and Development (IIED), London, UK.

Hasan, A., Girona, M.M., Grosbois, G., Saha, N., Halim, M.A. 2020. Land sparing can maintain bird diversity in northeastern Bangladesh. Sustainability, 12: 6472.

Islam, K.N., Rahman, M.M., Jashimuddin, M., Hossain, M.M., Islam, K., Faroque, M.A. 2019. Analyzing multi-temporal satellite imagery and stakeholders' perceptions to have an insight into how forest comanagement is changing the protected area landscapes in Bangladesh. Forest Policy and Economics, 101: 70-80. 
Islam, K., Majumder, S. C. 2015. Economic evaluation of Foy's Lake, Chittagong using travel cost method. Online at https://mpra.ub.uni-muenchen.de/69249/. MPRA Paper No. 69249, posted 6 February 2016 13:45 UTC.

Kawsar, M.H., Pavel, M.A.A., Uddin, M.B., Rahman, S.A., Mamun, M.A.A., Hassan, S.B., Alam, M.S., Tamrakar, R., Wadud, M.A. 2015. Quantifying recreational value and the functional relationship between travel cost and visiting national park. International Journal of Environmental Planning and Management, 1: 84-89.

Landell-Mills, N., Porras, T.I. 2002. Silver bullet or fools' gold? A global review of markets for forest environmental services and their impact on the poor. International Institute for Environment and Development (IIED), London, UK.

Leh, F.C., Mokhtar, F.Z., Rameli, N., Ismail, K. 2018. Measuring recreational value using travel cost method (TCM): a number of issues and limitations. International Journal of Academic Research in Business and Social Sciences, 8: 1381-1396.

Lenzen, M., Sun, Y.Y., Faturay, F., Ting, Y.P., Geschke, A., Malik, A. 2018. The carbon footprint of global tourism. Nature Climate Change, 8: 522-528.

Limaei, S. M., Safari, G., Merceh, G. M. 2017. Non-market valuation of forest park using travel cost method (case study: Saravan forest park, north of Iran). Australian Journal of Forest Science. 134. Jahrgang (2017), Heft 1, S. 53-74.

Limaei, S. M., Ghesmati, H., Rashidi, R., Yamini, N. 2014. Economic evaluation of natural forest park using travel cost method (case study, Masouleh Forest Park, north of Iran). Journal of Forest Science, 60: 254261.

Loomis, J., Yorizane, S., Larson, D. 2000. Testing significance of multi-destination and multi-purpose trip effects in a travel cost method demand model for whale watching trips. Agricultural and Resource Economics Review, 29: 183- 191.

Menkhaus, S., Lober, D.J. 1996. International ecotourism and the valuation of tropical rainforests in Costa Rica. Journal of Environmental Management, 47: 1-10.

Mree, C.L., Das, S., Ray, T.K. Chowdhury, P., Saha, N. 2020. Residents' perception of ecotourism in Ratargul Freshwater Swamp Forest of Bangladesh. Asian Journal of Research in Agriculture and Forestry, 5: 1-11.

Mukul, S.A., Biswas, S.R., Rashid, A.Z.M.M. 2018. Biodiversity in Bangladesh. In: Pullaiah T (Ed.), Global Biodiversity, Volume 1: Selected Countries in Asia. Apple Academic Press, Canada, pp. 93-107.

Mukul, S.A., Saha, N. 2017. Conservation benefits of tropical multifunctional land-uses in and around a forest protected area of Bangladesh. Land, 6: 2. 
Mukul, S.A., Sohel, M.S.I., Herbohn, J., Inostroza, L., König, H. 2017a. Integrating ecosystem services supply potential from future land-use in protected area management: A Bangladesh case study. Ecosystem Services, 26: 355-364.

Mukul, S.A., Rashid, A.Z.M.M., Khan, N.A. 2017b. Forest protected area systems and biodiversity conservation in Bangladesh. In: Mukul, S.A., Rashid, A.Z.M.M. (eds.), Protected Areas: Policies, Management and Future Directions. Nova Science Publishers, USA, pp. 157-177.

Mukul, S.A. 2014. Biodiversity conservation and ecosystem functions of traditional agroforestry systems: case study from three tribal communities in and around Lawachara National Park. In: Chowdhury, M.S.H. (ed.), Forest conservation in protected areas of Bangladesh: Policy and community development perspectives. Springer, Switzerland, pp. 171-179.

Mukul, S.A., Rashid, A.Z.M.M., Uddin, M.B. 2012. The role of spiritual beliefs in conserving wildlife species in religious shrines of Bangladesh. Biodiversity, 13: 108-114.

Mukul, S.A. 2008. The role of traditional forest practices in enhanced conservation and improved livelihoods of indigenous communities: case study from Lawachara National Park, Bangladesh. Proceedings of the 1st international conference on 'Forest Related Traditional Knowledge and Culture in Asia' held in Seoul, Korea during 5-10 October, 2008, pp. 24-28.

Mukul, S.A. 2007. Biodiversity conservation strategies in Bangladesh. The state of protected areas. Tigerpaper, 34: 28-32.

Muryani, Prabugati, G. 2016. An economic evaluation of ecotourism using travel cost method approach. International Journal of Research in Advent Technology, 4: 56-63.

Nadiruzzaman, M., Rahman, R. 2021. Ecosystem services: meanings, politics, developments, and way forward. In: Leal Filho, W., Azul, A., Brandli, L., Lange Salvia, A. and Wall, T. (eds.), Life on Land, Encyclopedia of the UN Sustainable Development Goals. Springer, Switzerland, pp. 306-316.

Ortega, S.T., Alvarez, R. P., Simal, P.D., Ruiz, J.M.D.L., Garcia, F.P. 2018. Economic valuation of cultural heritage: application of travel cost method to the National Museum and Research Center of Altamira. Sustainability, 10: 2550 .

Ota, L., Mukul, S.A., Gregorio, N., Herbohn, J. 2021. Community based management of tropical forests: lessons learned and implications for sustainable forest management. In: Blaser, J., Hardcastle, P. (eds.), Achieving Sustainable Management of Tropical Forests. Burleigh Dodds, Cambridge, UK, doi: 10.19103/AS.2020.0074.24.

Pant, M.M. 1984. Forest economics and valuation. Medhawi Publishers, Dehradun, India.

Pavel, M.A.A., Mukul, S.A., Uddin, M.B., Harada, K., Khan, M.A.S.A. 2016. Effects of stand characteristics on tree species richness in and around a conservation area of northeast Bangladesh. Journal of 
Quazi, S.A., Ticktin, T. 2016. Understanding drivers of forest diversity and structure in managed landscapes: Secondary forests, plantations, and agroforests in Bangladesh. Forest Ecology and Management, 366: 118-134.

Rahman, H.T., Shil, S.R. 2012. Measuring service satisfaction of young tourists: a case study of Lawachara National Park, Bangladesh. Anatolia, 23: 196-206.

Rana, M.P., Sohel, M.S.I., Mukul, S.A., Chowdhury, M.S.H., Akhter, S., Alam, M., Chowdhury, Q., Koike, M. 2010. Implications of ecotourism development in protected areas: a study from Rema-Kalenga Wildlife Sanctuary, Bangladesh. iForest - Biogeosciences and Forestry, 3: 23-29.

Saha, N. 2021. Tropical forest and sustainability: an overview. In: Leal Filho, W., Azul, A., Brandli, L., Lange Salvia, A. and Wall, T. (eds.), Life on Land, Encyclopedia of the UN Sustainable Development Goals. Springer, Switzerland, pp. 1070-1078.

Saha, N., Azam, M.A. 2004. The indigenous hill-farming system of Khasia tribes in Moulvibazar district of Bangladesh: status and impacts. Small-scale Forest Economics, Management and Policy, 3: $273-281$.

Salam, M.A., Lindsay, G.R., Beveridge, M.C. 2000. Eco-tourism to protect the reserve mangrove forest the Sundarbans and its flora and fauna. Anatolia, 11: 56-66.

Sands, R. 2005. Forestry in a Global Context. CABI, Oxfordshire, UK.

Sinha, K., Baten, M.A. 2021. Regulating Ecosystem Services: Enhancements Through Sustainable Management. In: Leal Filho, W., Azul, A., Brandli, L., Lange Salvia, A. and Wall, T. (eds.), Life on Land, Encyclopedia of the UN Sustainable Development Goals. Springer, Switzerland, pp. 828-840.

Sohel, M.S.I., Mukul, S.A., Burkhard, B. 2015. Landscape's capacities to supply ecosystem services in Bangladesh: A mapping assessment for Lawachara National Park. Ecosystem Services, 12: 128-135.

Solikin, A., Rahman, R.A., Saefrudin, E., Suboh, N., Zahari, N.H., Wahyudi, E. 2019. Forest valuation using travel cost method (TCM): cases of Pahang National Park and Srengseng Jakarta Urban Forest. Planning Malaysia: Journal of the Malaysian Institute of Planners, 17: 365-376.

Spacek, J., Antouskva, M. 2013. Individual single-site travel cost model for Czech Paradise Geopark. ActaUniversitatisAgriculturaeetSilviculturaeMendelianaeBrunensis, 2013, LXI, No. 7, pp. 2851-2858.

Uddin, M.S., van Steveninck, E.R., Stuip, M., Shah, M.A.R. 2013. Economic valuation of provisioning and cultural services of a protected mangrove ecosystem: A case study on Sundarbans Reserve Forest, Bangladesh. Ecosystem Services, 5: e88-e93. 
Uddin, M.Z., Hassan, M.A. 2010. Angiosperm diversity of Lawachara National Park (Bangladesh): A preliminary assessment. Bangladesh Journal of Plant Taxonomy, 17: 9-22.

Ward, F.A. 2000. Valuing nature with travel cost models: a manual. Edward Elgar, Cheltenham, UK.

Weaver, D. 2008. Ecotourism. $2^{\text {nd }}$ edition. John Wiley and Sons, USA.

World Bank. 2004. How much is an ecosystem worth? Assessing the economic value of conservation. World Bank, Washington, DC, USA.

World Bank. 1995. Valuing forests: context, issues and guidelines. FAO Forestry Paper 127. World Bank, UNEP, FAO, Rome.

\section{Figures}




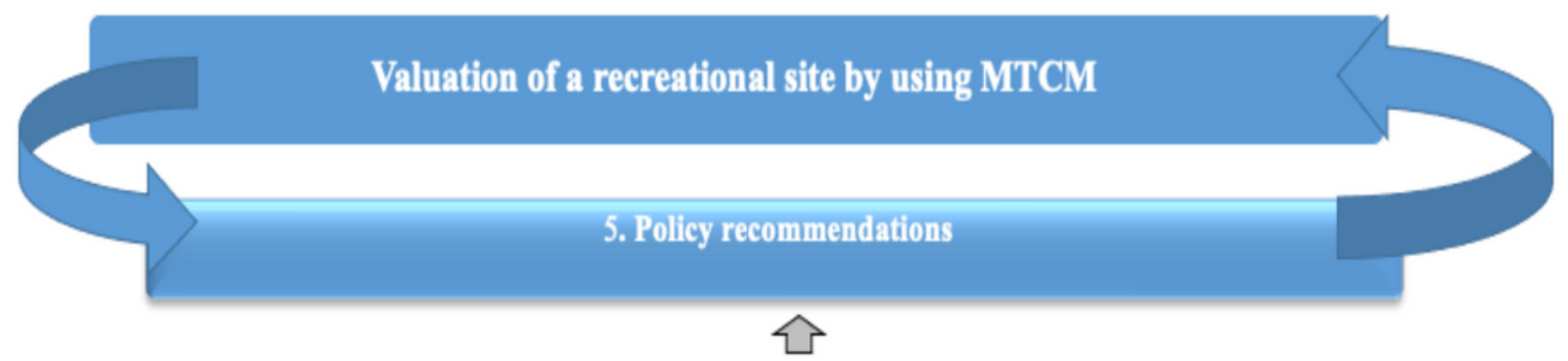

4. Estimation of value of a recreational site using TCM/ZTCM and MTCM

4.1. Demographic information relevant for analysis

4.2. Travel Characteristics: Origin of travel; travel cost; travel time; travel distance; means of travel; multi-purpose/multi-destination visits;

4.3. Activity characteristics: 0 ther costs (activity expenses) excluding food value; group/individual visits; activity time

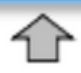

3.1. Final data collection

3.2. Data sorting and analysis

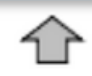

2.1. Conduct reconnaissance surveys

2.2. Data sorting and analysis

2.3. Prepare final semi-structure questionnaire

2.4 Final instruction to the Research Assistants/ Investigators

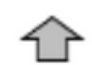

1.1. Literature acquisition

1.2. Study area selection

1.3. Semi-structure questionnaire design

1.4. Training of the Research Assistants/Investigators

\section{Figure 3}

Steps involved in the MTCM. 


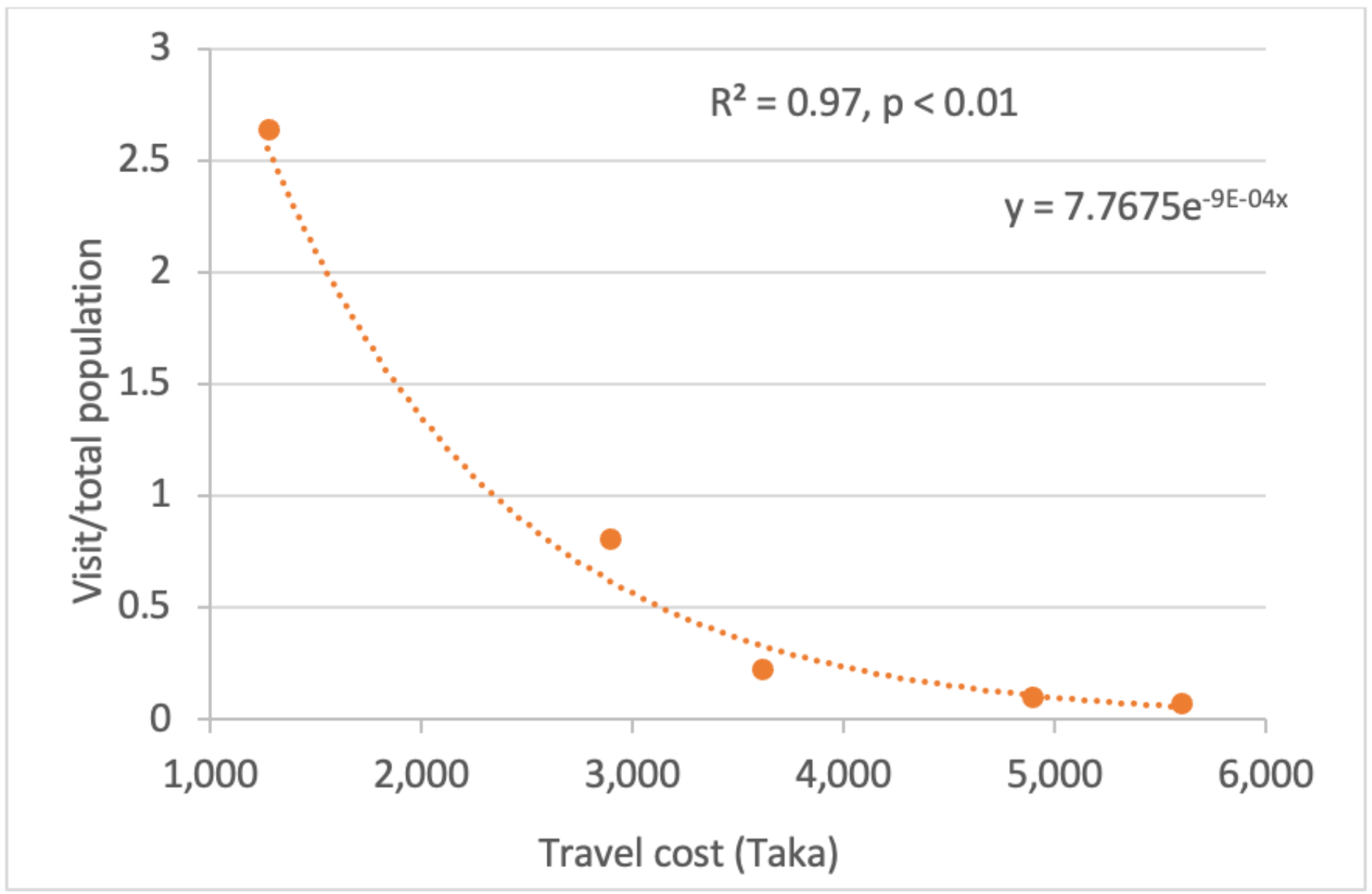

Figure 4

Relationship of travel cost and visiting LNP in the MTCM. 


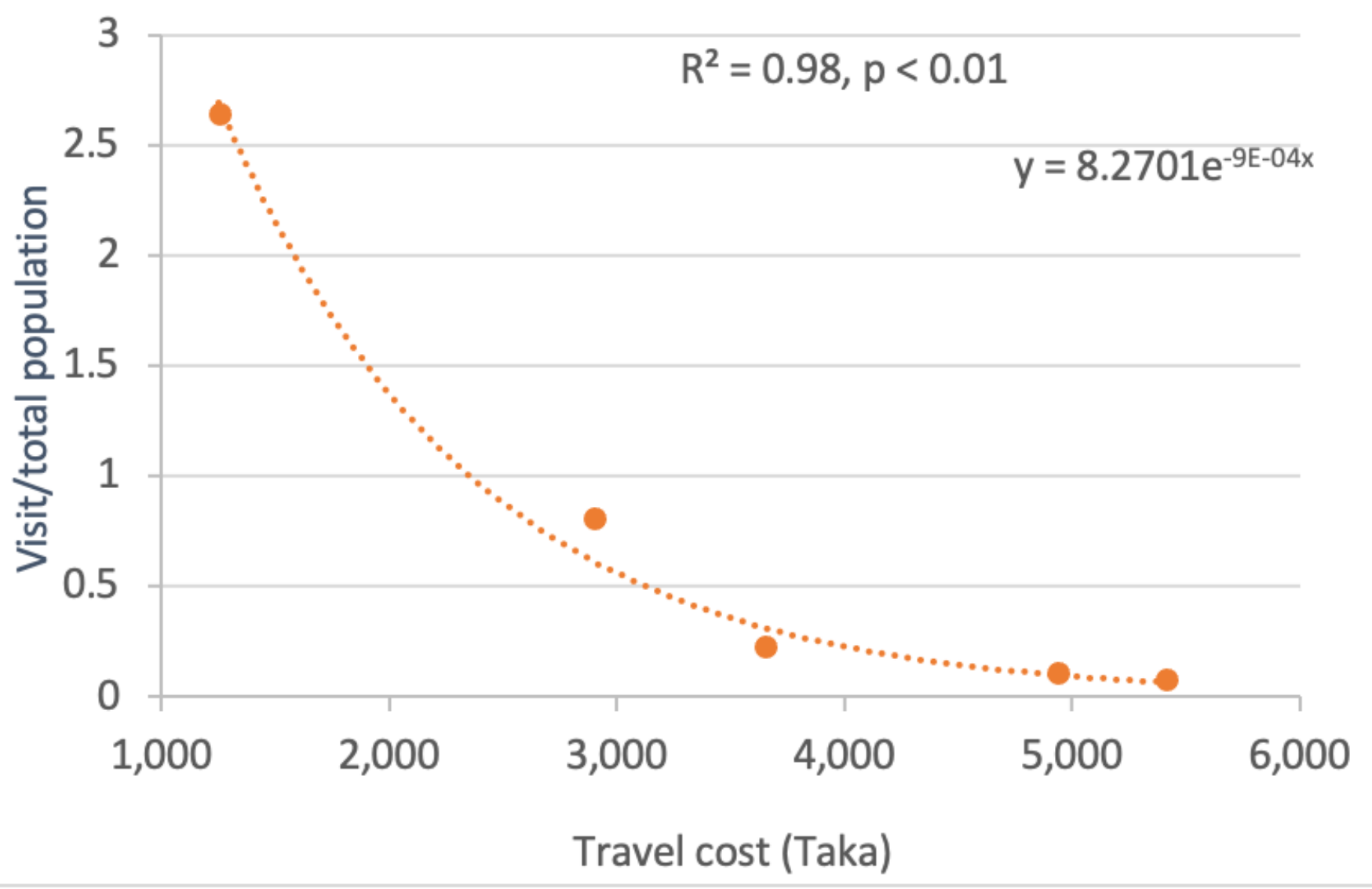

Figure 5

Relationship of travel cost and visiting LNP in the TCM. 